\title{
The delivery of recreation programs: Students gain entry level management skills through service learning
}

\begin{abstract}
Jo An M. Zimmermann' ${ }^{\text {, Jessica Dupree }}{ }^{2}$, and Jan S. Hodges ${ }^{2}$
Abstract: Service learning is a well established pedagogy within higher education. Specifically, service learning allows students to engage in 'real world' activities to practice skills and reflect upon their own competence. To enhance the effectiveness of service learning, instructors need to consider a multitude of learning influences. This study adhered to the tenants of the Social Cognitive Theory (Bandura, 1986; Schunk, 2004) to engage students enrolled in a 2000 level recreation program development course in service learning activities related to entry level administrative competencies. Data analysis included a content analysis of reflection papers $(n=186)$ to determine how many times competencies expected of entry level recreation professionals were mentioned. Students perceived the acquisition of competencies consistent with entry level competencies identified within the recreation industry. Findings contribute to the development of effective assignments to facilitate the acquisition of desired professional competencies.
\end{abstract}

Keywords: pre-service competencies, recreation management, recreation planning, program planning, service-learning, recreation education.

\section{Introduction}

The recreation industry is a varied field that includes many types of agencies and clientele with which professionals may work. Graduates of recreation administration degree programs often work in settings such as public/government recreation agencies (i.e. park and recreation departments), non-profit service agencies, commercial organizations (i.e. fitness centers and special event planners), and therapeutic agencies serving people with disabilities. Thus, recreation educators are challenged to provide experiences that will prepare students with competencies to meet this broad arena of opportunity.

With such a varied career potential, determining a core set of expectations for new professionals could be daunting. The Council on Accreditation of Parks, Recreation, Tourism and Related Professions (COAPRT) via the National Recreation and Park Association (NRPA) accredits undergraduate programs in parks, recreation, tourism, sport management, event management, therapeutic recreation and leisure studies. This accreditation program offers some direction when it comes to understanding what competencies students should obtain in order to be successful in the recreation industry. According to COAPRT standard 7.01:

Students graduating from the program shall demonstrate the following entry-level knowledge: a) the nature and scope of the relevant park, recreation, tourism or related professions and their associated industries; b) techniques and processes used by

\footnotetext{
${ }^{1}$ Department of Health and Human Performance, Texas State University, jz15@txstate.edu

${ }^{2}$ Department of Health and Human Performance, Texas State University
} 
professionals and workers in these industries; and c) the foundation of the profession in history, science and philosophy (COAPRT, 2014, p.13).

The research reported in this paper focused on part b of standard 7.01 which requires students to demonstrate "techniques and processes used by professionals and workers in these industries" (COAPRT, 2014, p. 13). As such, we looked to identify specific skills or competencies used by professionals in the recreation industry.

Existing research on competency includes skills, knowledge and characteristics related to success in employment responsibilities (Hurd, 2004b). To date, recreation related literature includes identified competencies associated with agency CEOs (Hurd \& Buschbom, 2010; Hurd \& McLean, 2004), entry level professionals (Hammersley \& Tynon, 1998; Hurd, 2005), and sport administration personnel (Barcelona \& Ross, 2004; Jamieson, 1987). In addition, Hurd, Barcelona \& Meldrum (2008) confirmed a list of competencies that are needed by an entry level recreation professional.

The research examining competencies needed by entry-level professionals identified 40 different competencies in six categories (Hurd et al., 2008). The categories are business acumen, communication, community relations, interpersonal skills, management techniques, and planning and evaluation. Refer to Appendix 1 for specific competencies in each of the identified categories.

Although established entry level competencies exist, according to Barcelona, Hurd, and Bruggeman (2011) there is uncertainty about the best pedagogical method to develop these competencies. According to Olsen and Burke (2014), "the challenge is not teaching the concepts ... but rather in developing undergraduate students' ... skills through instruction and practical application of the theories and strategies" (p. 76) as presented in textbooks. Further, Crossley, Jamieson, and Brayley (2007) suggest that some personal attributes and skills needed by professionals in the recreation industry are difficult to teach via traditional academic methods such as lecture. "As recreation is predominately a leisure activity, learning how to plan and implement ... [activities] or program[s] cannot be done through theoretical classes alone" (Coetzee, Hermanus, Bloemhoff, \& Luzelle, 2011, p. 549). Thus a popular approach is the inclusion of service learning experiences within academic courses, where students have reported perceived achievement of a-priori competencies through service learning (Coetzee et al., 2011). This is supported by comments from an Athletics Supervisor for a city parks and recreation department who works with undergraduate students on service-learning projects:

Unfortunately, the current job market is not what I would refer to as an ideal opportunity for college graduates. Competition for entry level supervisors has increased considerably over the past five years. College graduates need relevant experience to complement their degree. In addition, interview questions are typically going to focus on the practical application of service delivery rather than a theory based approach. It is essential that graduates bring practical experience to interviews and this [service learning] project ultimately makes them more marketable as a prospective employee (Werner, 2011).

\section{Service Learning and Recreation Education}

Bringle and Hatcher (1997) define service learning as a:

type of experiential education in which students participate in service in the community and reflect on their involvement in such a way as to gain a further understanding of 
course content and of the discipline and of its relationship to social needs and an enhanced sense of civic responsibility (p. 153).

Within the recreation literature, Stevens (2008) suggests that "service learning is a hands-on class project in which you learn by helping others, discover how class knowledge is useful in the real world, master practical skills ... and gain an appreciation for diversity" (p.xii). As a teaching method within the field of recreation, service learning is by no means a new concept. However, research on the outcomes of service learning in recreation programs appears to be limited. A literature search of the primary journals in recreation and leisure studies revealed fewer than two dozen articles that included the key words of both service learning and recreation education or recreation. Examples include reports on various types of community-based projects: (Cucina \& McCormack, 2001; Hendricks \& Miranda, 2003; Moorman \& Arellano-Unruh, 2002; Mumford \& Kane, 2006; Ostiguy \& Hopp, 1995; Petersen, Judge, \& Pierce, 2012; Riley, 2006; Smith, 2003); articles about the use of journals and the reflection process (Baccarro, 2003; Coetzee et al., 2011; Cooke \& Kemeny, 2014; Olsen \& Burk, 2014); the use of students as peer advisors (Stringer \& Kowalski, 2003); and two which seemed to focus more on the process and outcomes of service learning (Ruan, Edginton, Chin, \& Mok, 2014; Williams \& Lankford, 1999).

In regard to the importance of service learning to academic preparation of new professionals, a Recreation Division Manager, for a city parks and recreation department commented:

As a student coming out of a program where service learning was important I not only felt prepared to do my job, I also felt confident that I was given every opportunity in my education to gain all necessary skills to make me ready. As a professional in the field of parks and recreation ... I have also had the opportunity to work with students coming out of a different university program where service learning is not emphasized and I see the difference in their abilities and readiness to perform the tasks of planning and executing a program or special event. The service learning aspect of classes allows the students to get firsthand experience working with agencies in the community, thus building skills as well as community relationships between the university and its surrounding cities and towns. I feel that service learning is not only necessary for true growth of a student; I feel it is essential for students to be prepared to go into the real world (Flores, 2011).

Although literature about service learning specific to recreation administration curriculum is scant, numerous studies in other disciplines have demonstrated its effectiveness. According to Sax and Astin (1997) participation in service learning leads to increased knowledge in that student's discipline. Examples supporting this statement were found in teacher education (Meaney, Housman, Cavazos, \& Wilcox, 2012; Meaney, Griffin, \& Bohler, 2009), journalism (Cohen \& Kinsey, 1994), human organizational development (Giles \& Eyler, 1994), and health education (Housman, Meaney, Wilcox, \& Carazos, 2012). In addition to discipline specific literature related to service learning, there were numerous other articles related to the moral and character development of students (Batchhelder \& Root, 1994; Bernacki \& Jaeger, 2008; Reed, Jernstedt, Hawley, Reber, \& DuBois, 2005), increases in civic responsibility and intentions to participate in community service (Astin \& Sax, 1998; McCarthy \& Tucker, 2002); as well as changes to a students' global perspective, or their tolerance towards groups with which they normally did not interact (Engberg \& Fox, 2011; Morgan \& Streb, 2001).

Based on the available literature in recreation, there appears to be a limited amount of research connecting service-learning to specific competencies and skills regarded as necessary in the field of recreation (Coetzee et al., 2011; Olsen \& Burk, 2014) and neither of those is tied to a 
theoretical framework beyond the accreditation standards set forth by The Council on Accreditation of Parks, Recreation, Tourism and Related Professions (COAPRT). Therefore, the purpose of this study was to explore which competencies students would perceive as achieved through participation in a service learning project, designed according to the indices of the social cognitive theory. This was a descriptive study with a content analysis based on a series of students' reflection papers in an undergraduate recreation class with a required service learning component.

\section{Theoretical Framework}

The impact of service learning on students' ability to understand and apply the principles related to developing, implementing and evaluating a recreation program can be explained by aspects of the Social-Cognitive Theory (SCT). Bandura (1986) suggests that SCT explains human functioning as the interaction of internal personal factors, behavioral patterns and environmental influences. According to Schunk (2004), a recognized scholar in educational learning theories, SCT is a theory about observational learning that enhances the acquisition and performance of competencies, where learning is contingent on the social environment.

A principle tenet of SCT involves the concept of triadic reciprocal determinism that suggests changes in behavior occur because dynamic social settings promote interactions between one's personal factors, environment, and behavior (Schunk, 2004). Figure 1 represents how the factors of SCT interact. Personal factors may include a learner's knowledge, perceived self-efficacy, behavioral capacity, outcome expectations, fears, and goals related to a given social situation (Housman et al., 2012). According to Schunk, the environment includes any social, economic, policy, legal, or physical influence that can act on behavior including learning new skills, autonomy, and persistence.

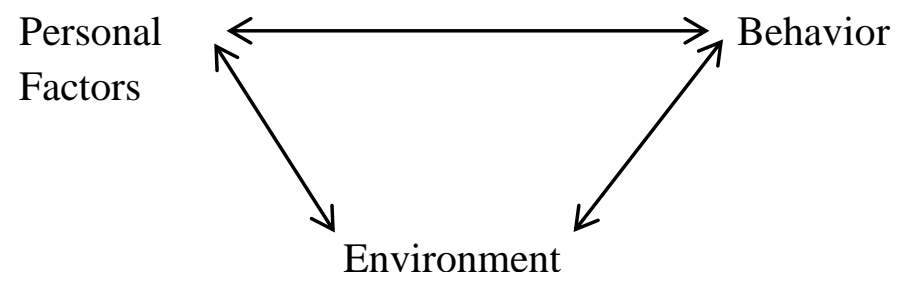

Figure 1. A model illustrating the interactive factors of Social Cognitive Theory (SCT). Schunk 2004.

Although SCT has not been used as a framework to understand learning in recreation degree programs, it has been effectively used in other disciplines. For example, Housman et al. (2011) used SCT to demonstrate how students in a health education program improved perceived self-efficacy as well as cultural competence through participation in a service-learning project. In addition, Meaney has conducted research with both undergraduate (Meaney, Griffin, \& Bohler, 2009) and graduate (Meaney et al., 2012) pre-service physical education majors using an SCT framework.

According to SCT, to best understand how students learn it is imperative to consider the full range of the environment where students are engaged in learning activities (Schunk, 2004). 
Therefore in a course with a service learning component, the classroom as well as the service learning environment must be considered. For the purposes of this study, the environment in the context of the service learning project includes the type of agency to which the students are assigned, the clientele and the agency representatives with whom the students work. The behavior in this study refers to skill acquisition, namely the competencies which students perceived they utilized or gained. According to SCT, personal student factors combined with the environment result in behavior (Schunk, 2004).

\section{Methods}

This study occurred over two academic semesters involving student reflection about their learning as related to participation in a service learning project to plan and deliver a recreation program. The Social-Cognitive Theory (SCT) model guided the planning of service learning projects to achieve desired learning outcomes. Two specific issues were influenced by SCT: 1) the instructor specifically sought out projects from a variety of recreation agencies which served different types of clientele so as to have a varied environment; and 2) the instructor intentionally included questions in each reflection paper that related to SCT. This approach allowed for rich description attained from the words of students prior to, during, and after their service learning experience.

\section{Participants}

Participants were enrolled in a recreation program development course at a state university in the southwest United States. It is a 2000 (sophomore) level class restricted to recreation majors and minors that requires 2 prerequisite courses in the recreation administration degree program prior to enrollment. Due to these prerequisites, students were not eligible to take this course until at least their second semester in the program. In the fall semester 28 students (11 male, 17 female) worked with eight special events. The age range of the students was 19-31 years with an average age of 22.86. In the spring semester, 35 students (18 male, 17 female) were assigned to nine special events. The age range of the students was 20-51 years with an average age of 23.83. All students enrolled in the course were required to participate in the service learning component as a graded portion of the course. Permission from the University Human Subject's Review Board was obtained prior to data collection.

\section{The Service Learning Project}

Prior to each semester the instructor worked with a variety of local recreation providers, such as park and recreation departments, local housing authority, and private nonprofit disability services agencies, to organize the service learning assignment. Agency supervisors were provided a written description of the project requirements (students needed to help design, implement and evaluate a special event) prior to agreeing to participate. In addition, agency supervisors could assign tasks and deadlines relating to the event beyond the course requirements if necessary for the success of the event. Agency supervisors were asked to serve as mentor, guide, and supervisor for one or more events. The agency supervisor decided for which events they were willing to accept student groups, and determined how many students could be utilized 
appropriately for a particular event. In each semester there was a mix of public agencies offering free programs, public agencies offering programs for which participants paid an entry fee, and nonprofit agencies offering free programs.

At the first class meeting of the semester, students received a list of agencies, events, and dates. On the third class day, agency representatives attended class to share additional information regarding their specific events such as target market and an overview of the student work tasks. Following these presentations, each student rank-ordered their top four event preferences. The instructor then used these ranking sheets to assign three-five students to each event.

During the semester, students were allotted time in class to work on their respective events; however, the majority of project work was outside of class. Most groups had weekly meetings with their agency supervisors. Although each event was unique, all students had assignments that included; planning, implementation, and evaluation of a special event. In the process of completing this assignment students were involved in tasks such as seeking donations and sponsorships, marketing for volunteers and participants, developing risk management plans and documenting the event by creating a written program plan.

Agency supervisors provided group and individual ratings on professionalism (preparedness for meetings, meeting deadlines) and quality of work (following through on tasks, asking appropriate questions, communication, working independently, and response to constructive feedback) after completion of the project. Students were aware in advance that this evaluation would contribute to the grade which they would earn for their service-learning project.

\section{Data Collection}

Data were collected during the 2011-12 academic year. The student reflection process included three written reflections based on guiding questions. Questions were developed in accord with professional literature about established competencies within the recreation industry (Hurd et al., 2008) and the indices considered in Social-Cognitive Theory (SCT) to be influential on student learning (Schunk, 2004).

The first reflection paper, submitted a week after their initial meeting with the agency, focused on personal factors that could impact the learning process such as student apprehensions and expectations for the project, predictions about where they thought their group would excel, and feelings about the environment to which they were assigned. The second reflection paper, submitted one week prior to their event, asked each student to reflect on their personal role in the project (behaviors); areas they need to improve upon (personal factor and behavioral capacity) as well as asking if they felt prepared for the event (personal factor - self efficacy). The third reflection paper, submitted one week after the event, asked them to compare original expectations to what actually happened (behaviors), as well as things they learned through the project which they perceived they could not have learned in a classroom (environment linked to behaviors).

Students were asked to write openly and honestly on the reflection papers. To encourage this, students were informed prior to assignments that papers would be graded based on quality and thoroughness of the responses, not on the actual perception of the event. For instance, grading was not affected by whether the grader liked or agreed with the response; but rather how thoroughly the student responded. 


\section{Data Analysis}

All reflection papers submitted by students were included in analysis. A total of 186 reflection papers were analyzed, including 63 First, 63 Second, and 60 Third papers. Content analysis was conducted on answers to eight questions from the reflection papers which related specifically to Social-Cognitive Theory (SCT). Due to the volume of data, the researchers decided to conduct a conceptual analysis which required that they identify how many times specific words or phrases were used in the text being evaluated. This is the most traditional form of content analysis when researchers choose a concept and then seek to quantify and tally its presence in the documents under review (Busch et al., 2014). The reflection papers covered a number of topics not considered in this paper therefore focusing on just those concepts which were of interest to the researchers was the most appropriate method of analysis. Two researchers independently reviewed all the reflection papers seeking to identify content specific to the entrylevel competencies as defined by Hurd et al. (2008). See Appendix \#1 for the complete list of competencies.

Following the procedures identified in the literature for content analysis (Crewswell, 2009; Busch et al., 2013), researchers created a qualitative codebook consisting of the 40 competencies needed by entry-level recreation professionals. To increase reliability and minimize coding errors, the researchers initially agreed to look for specific words or groups of words that contained the explicit terms for which they were looking. For example, 'learning to manage time' was to be counted as 'time management'. In addition, they were to highlight implicit terms or phrases that seemed to be about competencies but did not actually include the explicit terms. Each of the researchers then conducted a manual frequency count of the explicit terms under investigation. Following the individual coding, comparison revealed 100\% agreement on the explicit terms. After some discussion regarding implicit terms or phrases it was decided that while the researchers preferred to stay with explicit terms the majority of the time, there were a few cases where including implicit terms was appropriate. Two examples of implicit terms included in the final count were the words 'sponsorship' and 'donations'. Those words are not in the table of competencies; however, practice and literature (Allen, O'Toole, McDonnell, Harris, \& Stokes, 2005; Cornwell, 2010; Janes, 2009) in the discipline list both as marketing functions. Therefore, anytime the students mentioned 'sponsorship' or 'seeking donations' it was coded as marketing. Additional implicit terms examined were 'risk management' which was included under 'laws and legal matters', 'being adaptable' which was coded under 'be flexible', and 'taking charge' which was coded as 'leadership skills and abilities'. Other terms did not really fit under a competency or relate to SCT factors and were therefore ignored in the coding process.

\section{Findings}

The three reflection papers were graded assignments. However, three of 63 students did not complete the third reflection paper, resulting in a $95.2 \%$ return rate. In total there were eight questions across the three reflection papers that directly related to personal factors, environment, and behavior as suggested by the triadic reciprocal determinism of Social-Cognitive Theory (SCT). Consolidating the data from both semesters, students reported learning/having to use 32 different competencies in the areas of business acumen, communications, community relations, 
interpersonal skills and management techniques. None of the students mentioned any of the competencies in planning and evaluation. Table 1 shows how many times the competencies were mentioned in reflection papers by semester and for the year.

\section{Table 1}

Competencies reported in reflection papers

\begin{tabular}{|c|c|c|c|c|}
\hline \multicolumn{2}{|c|}{$\begin{array}{l}\text { Entry Level Professional Competencies mentioned by students in reflection } \\
\text { papers }\end{array}$} & Fall 2011 & Spring 2012 & $\begin{array}{l}\text { Total across the } \\
\text { academic year }\end{array}$ \\
\hline \multicolumn{2}{|c|}{ Business Acumen } & & & \\
\hline 1 & Understand financial processes (i.e., purchasing, budget) & 0 & 1 & 1 \\
\hline 2 & Develop, monitor, and stay within a budget & 24 & 8 & 32 \\
\hline 3 & Possess knowledge of management principles & 0 & 1 & 1 \\
\hline 4 & $\begin{array}{l}\text { Demonstrate basic knowledge of laws and legal matters affecting } \\
\text { the field }\end{array}$ & 1 & 8 & 9 \\
\hline \multicolumn{2}{|c|}{ Communications } & & & \\
\hline 6 & Clearly communicate with staff, customers, and the public & 28 & 27 & 55 \\
\hline 7 & Possess effective written and oral communication skills & 2 & 0 & 2 \\
\hline 8 & Listen to staff and customers & 1 & 2 & 3 \\
\hline 9 & Implement marketing techniques & 38 & 50 & 88 \\
\hline 10 & Communicate the organization's values, vision, and mission & 1 & 0 & 1 \\
\hline \multicolumn{2}{|c|}{ Community Relations } & & & \\
\hline 11 & Know the community and its needs & 10 & 5 & 15 \\
\hline 12 & Understand customer service practices & 1 & 0 & 1 \\
\hline 13 & Have the ability to deal with the public & 2 & 4 & 6 \\
\hline 14 & Develop partnerships with other organizations & 1 & 0 & 1 \\
\hline \multicolumn{2}{|c|}{ Interpersonal Skills } & & & \\
\hline 16 & Be creative and innovative & 24 & 29 & 53 \\
\hline 17 & Be flexible & 2 & 10 & 12 \\
\hline 18 & Have patience & 1 & 3 & 4 \\
\hline 19 & Be enthusiastic and have a positive attitude & 9 & 7 & 16 \\
\hline 20 & Be open-minded & 2 & 2 & 4 \\
\hline 21 & Deal with personality conflicts & 0 & 2 & 2 \\
\hline 22 & $\begin{array}{l}\text { Understand the concept of criticism and accept constructive } \\
\text { criticism }\end{array}$ & 1 & 0 & 1 \\
\hline 23 & Take initiative & 1 & 2 & 3 \\
\hline \multicolumn{2}{|c|}{ Management Techniques } & & & \\
\hline 24 & Use effective problem-solving and conflict-resolution skills & 7 & 13 & 20 \\
\hline 27 & Supervise, discipline, and evaluate a diverse staff & 0 & 1 & 1 \\
\hline 28 & Motivate employees & 2 & 0 & 2 \\
\hline
\end{tabular}

Journal of the Scholarship of Teaching and Learning, Vol. 14, No. 4, October 2014. 


\begin{tabular}{|l|l|c|c|c|}
\hline 29 & Have leadership skills and abilities & 9 & 18 & 27 \\
\hline 30 & Be able to work in a team & 14 & 42 & 56 \\
\hline 31 & Use effective organizational skills & 8 & 19 & 27 \\
\hline 32 & Prioritize and manage multiple tasks & 4 & 1 & 5 \\
\hline 33 & Demonstrate effective time-management skills & 37 & 35 & 72 \\
\hline 34 & Conduct program evaluations & 2 & 0 & 2 \\
\hline 35 & Schedule programs, leagues, and staff & 0 & 1 & 1 \\
\hline 36 & Network within and outside the profession & 3 & 2 & 5 \\
\hline Totals & & 235 & 293 & \begin{tabular}{c} 
528 \\
\hline
\end{tabular} \\
\hline & $\begin{array}{c}\text { 27 } \\
\text { competencies } \\
\text { least 1 time }\end{array}$ & $\begin{array}{c}\text { 25 } \\
\text { competencies } \\
\text { least 1 time }\end{array}$ & $\begin{array}{c}\text { 32 Different } \\
\text { competencies } \\
\text { mentioned at } \\
\text { least 1 time } \\
\text { across the } \\
\text { academic year }\end{array}$ \\
\hline
\end{tabular}

\section{Discussion}

Social-Cognitive Theory (SCT) provides a theoretical framework to understand how students learn the competencies needed for a successful career in recreation. The discussion will therefore center on the three categories of influences identified within SCT as impacting learning outcomes. Figure 2 is a visual representation of the major findings. The section will conclude with a discussion of the limitations of the study.

Personal Factors

- Understanding the need to use leadership and teamwork to complete the project

- $\quad$ Expressed concerns regarding time management and marketing

- $\quad$ Predicted success in creativity and innovation

- Identified the need to improve on communication

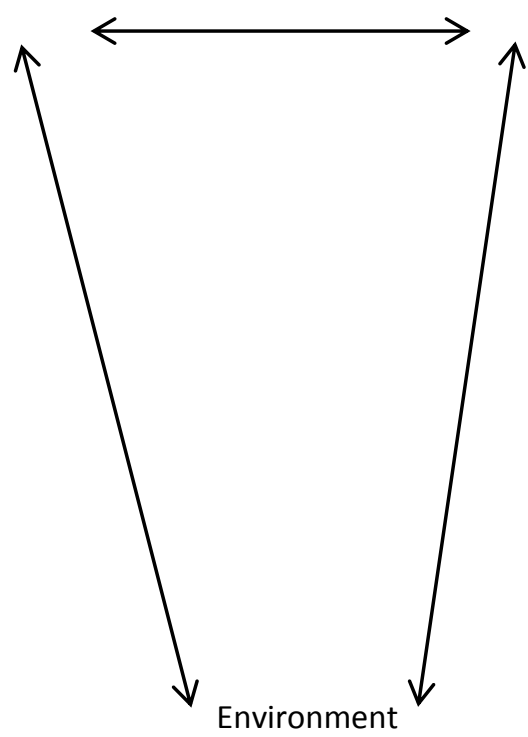

Interaction with recreation professionals in local agencies to plan, implement and evaluate a special event for a specific target audience
Behavior

- Student Roles - marketing, creativity and communication with staff, customers and public

- Out of class learning - problem solving \& conflict resolution skills, marketing techniques and the importance of hands-on actually doing what they are learning

Figure 2. Major Findings

Journal of the Scholarship of Teaching and Learning, Vol. 14, No. 4, October 2014. 


\section{Personal factors}

As discussed previously, personal factors may include a learner's knowledge, perceived self-efficacy, behavioral capacity, outcome expectations, fears, and goals related to a given social situation (Housman et al., 2012). The first and second reflection papers both included questions about personal factors.

The first reflection paper focused on the personal factors of expectations regarding the project, anything they might be concerned or worried about, and predictions as to areas in which their group would excel. Selected student quotes follow the findings for each question:

Personal Factor: Expectations. Regarding expectations, of the 63 students who submitted Reflection Paper 1, 18\% ( $\mathrm{n}=11)$ thought that implementing marketing techniques would be a difficult task, and 16\% ( $\mathrm{n}=10)$ mentioned they would excel at having leadership skills or being able to work in a team.

I expect to learn a lot from this project. I expect to learn how to compose a sponsorship plan and spread the word about an event ... I feel that this project will give me first-hand experience to feel confident when doing this in my future career.

Personal Factor: Fears/Concerns. When asked what fears/concerns they had, 28 (45\%) students responded with "demonstrate effective time management skills". The second most frequent response was "implement marketing techniques," which $34 \%$ of the students $(n=21)$ wrote about.

The most difficult aspect of our project, in my opinion, will probably be time management and getting everything done in the small window that we have to do it. I also think that getting donations for different prizes we would like to have will be tough but not impossible.

I am nervous about going to potential sponsors to ask for support.

Personal Factor: Predictions of Areas of Group Success. Students mentioned 11 competencies in which they felt their project group would excel. The two competencies mentioned most frequently were "be creative and innovative" (17 or $27 \%$ ) and "be able to work in a team" (13 or $21 \%$ ). Comments related to these expectations included: "Once we all get together, we are extremely creative. Coming up with fun games for the kids and making the event an overall success will be very easy," and "I think my group will work together with a great sense of cohesion. We all want to put on a great event, and have some creative ideas to get it going."

The second reflection paper focused on the personal factors of self-efficacy (readiness for the event) and behavioral capacity (areas where they needed to improve upon). Student responses are below:

Personal Factor: Self-efficacy - Readiness for the event. The results from this reflection showed that 40 of the 63 students $(63.5 \%)$ stated that they felt completely prepared for the event. Two (3\%) responded 'somewhat', $7(11 \%)$ did not provide a definitive answer, and the remaining $14(22 \%)$ had versions of 'no'. Of the students responding 'no' that did not feel ready three $(4 \%)$ indicated that although feeling not fully prepared at that time, they expected tasks were doable and were confident they would be ready by event time. Five (8\%) responded that although they had to say 'no' at this time, they thought they were as prepared as possible. "Yes, I feel like the group and I are very prepared for the event. Our group has put in a lot of time and 
effort into this event and I believe all of that will pay off for us when our event takes place." Another student wrote,

I feel like my group and I are prepared for the event to an extent. The event's date was changed to three weeks earlier than planned and it has been chaotic trying to get everything to come together and find teams that want to participate during Spring Break...As far as the day of the event goes, I think we are prepared and know what to expect and what our roles are for that day.

Personal Factor: Behavioral capacity. Students were asked to reflect upon what area(s) they felt they needed to improve on most. Answers ranged from the very specific (such as need to improve on technical computer skills) to more broad answers like, "The thing I or our group need to improve on is communication." Communication was a very common answer amongst respondents, being the most frequently cited area to improve on (14 students, 22\%, answered in this area). Other popular responses included "time management" with 10 students (16\%) and "improved leadership" with 6 students (10\%).

In summary, when asked about personal factors students commented on the need to use leadership skills and teamwork if the project was going to be completed to a high standard. They expressed concerns regarding the amount of time they needed to commit to the project and whether or not they could manage their time effectively. They were also concerned about one marketing aspect - securing sponsorships and donations. They predicted success in the areas of creativity and innovation, feeling that each member of their team had something to contribute to the overall effort. At the end of the project they acknowledged the continuing need to improve upon communication as they work on similar projects in the future. These findings are consistent with what one might expect from early career recreation professionals. It is normal for students to be nervous about a large project which will require them to complete tasks which they may not have done previously. According to research conducted by Hurd, Elkins and Beggs (2014) prior to their final internship students indicated that they were more confident with interpersonal skills such as leadership and teamwork, and "less certain about competencies discussed in class but not yet experienced in the field" (p. 51) such as seeking sponsorships and donations.

\section{Behavior}

According SCT, behavior may include such things as learning new skills, autonomy and persistence (Schunk, 2004). Learning new skills is one of the primary benefits of service learning and it gives students the opportunity to gain practical experience. Students were asked one question each in reflection papers two and three which related to behavior.

Behavior: Personal Role in Project (reflection paper two). A total of 16 different competencies were mentioned in response to the prompt, "discuss your role in this project and what do you feel have been your most significant contributions." The most frequent response was "implement marketing techniques" (24 or 38\%), followed by 16 responses $(25 \%)$ for "be creative and innovative", and 14 (22\%) for both "clearly communicate with staff, customers and the public" and "demonstrate effective time management skills."

"I feel that my role in the project was a creative one. I worked hard on brainstorming new ways to do things, looking (for) non-traditional vendors, and designing flyers."

"One of the most important roles that I and others have had is that of communicator." 
"We all went out and spoke to potential sponsors individually and as a group. We, however, were all assigned a specific assignment that we were in charge of. My specific assignment was to gather volunteers. I have to make sure that we have the amount of volunteers needed to run the event smoothly."

Behavior: Expectations and Outcomes. After completing their event students were asked to compare original expectations to the actual outcome. Responses were grouped according to meeting expectations, exceeding expectations or not meeting expectations. Thirty eight students $(63 \%)$ reported that the experience matched their expectations. Four students reported that their expectations were higher than experienced in the actual event, and seven reported that the event exceeded their expectations. Two students were unable to answer the question because they changed groups after the first reflection paper, and nine students failed to answer thoroughly enough to use for data. Examples of responses include:

The expectations I had leading up to this event were very similar to what I experienced the day of the event. One of the expectations that I had was that all the kids would have fun doing the activities without harming themselves. My group members and I planned out each activity so they were all safe for all the participants... This event turned out to be a great experience that I can look back on in a positive light for the rest of my life.

My expectations for this event possibly were set too high. I was originally expecting there to be around 650 participants since ...we were told to expect around 500. After the event Erin told me that we actually had somewhere between 200 and 250 . I was really let down by that number...

When I first started working on the fest (actual event name removed by researchers) I was excited to be working on such a large event for the first time. After a couple of meetings we weren't getting the desired response from the art and food vendors. I was beginning to expect that the event would not be as large and we had hoped... The results of the festival far exceeded my expectations prior to the event.

In summary, the students were able to clearly state their roles in completing the assigned project. It is interesting to note that two of the top five responses regarding role of the student matched those about which students indicated concern in the first reflection paper (time management and marketing). Additionally, the issues the students reported in regards to expectation vs. outcomes upon completion of the project were closely related to the ones they had brought up under behavioral capacity as things they still needed to improve (communication skills, time management and leadership). Housman et al. (2011) stated "providing students with service-learning opportunities creates a sense of urgency on the student's behalf to effectively convert principles discussed in class to meet the needs of the community" (p.274). Having to design and implement an event for a local recreation agency (rather than just creating one on paper) not only created a sense of urgency it also provided a huge sense of accomplishment. As will be shown in the next section, the students learned many things which they would not necessarily have gained by staying in the classroom. 


\section{Environment}

Environmental influences that resulted in behavioral changes (Bandura, 1986), occurred both within the context of the classroom and at the agency location. Students were asked about environment in reflection papers one and three.

Environment (reflection paper one). Students were asked if they felt they had been provided with adequate information during the first meeting with the agency supervisor in regards to the agency as well as the event. Students responded that they had been provided with the following types of information: dates/deadlines, budget, tasks that required creativity, general layout of event, goals to achieve, list of available resources, information about the target audience and sponsors. No students mentioned not receiving needed information.

Environment Linked to Behavior: Out of Class Learning (reflection paper three). In response to what students perceived they learned that they would not have learned in a traditional classroom setting, students mentioned a total of 20 competencies. The most frequently mentioned competency was 'use of effective problem-solving and conflict resolution skills'. Twelve (20\%) reported experiencing that things did not go according to plan and having to problem solve in order to make things work was a great learning experience. For example:

What I learned from this project is that things cannot always go according to plan. Improvising is a major part of events and that is something that everyone must find out from experience. A classroom cannot teach me how to deal with a situation that pops up right in front of my face. Through creativity and effectiveness, we accomplished more than we imagined possible at the beginning of the semester.

Learning how to improvise and change things to better the program I don't think I could have learned in the classroom. You do not figure out how to improvise or be creative and use your head until you are at the event facing different obstacles. Learning to fix things and be creative and open minded can only be learned during program planning because it is more surreal and encourages you to make the program successful.

At our event while they were setting up the screen for the movie there was a malfunction that happened and we could not use that screen. It was good experience to see how our supervisor handled the situation and figured out what she wanted to do. We hear about those things in the classroom but don't get to see how they really play out.

The second most mentioned competency was "demonstrate effective time management skills". Twelve (20\%) students mentioned time management in their reflection papers. The third competency was "implement marketing techniques" which was mentioned by 11 students (18\%).

In addition to competencies, 18 students also commented about the hands-on experience (using the words "hands-on" or "firsthand") and how it changed their understanding of the techniques needed to successfully manage recreation programs.

A student can easily study how to camp, read how to put up a tent and hear how you can roast a perfect marshmallow. But it's not until you experience it on your own that you can honestly say you're able to put yourself in that position and relate to your participants. If I hadn't personally gone through the camping experience, then it would have been even more difficult for me to relate to my participants and group members. 
From completing this project I learned how time consuming even the smallest of projects can be. I also learned a lot about budgeting, legal issues, and the importance of networking. All of these things can be taught in the classroom, but to actually get hands on experience makes learning these concepts life lasting. If I had sat in the classroom and just taken a test over these concepts I would not have learned nearly as much.

If I had not gotten to have hands on experience working with this festival I do not believe I would have learned much at all. Reading about the preparation for a large event and then actually being the one moving barricades and posting signs around town at six in the morning are two much different ways of grasping the base concepts.

In the classroom, curriculum reflected the program planning process that students were actively engaged in at their agency site. It provided an opportunity to ask questions about what they were learning and receive information and feedback from the professor. The classroom complimented the service learning by providing an environment in which the students could reflect on experiences and seek guidance on how to proceed in an effective manner. It also provided a workspace for students to meet with their teams as there were multiple opportunities during the semester for students to work on group assignments. Group assignments were made based on student preferences and only rarely were students not placed in one of their top three choices. Once placed at the agency, students met with their supervisor and student group between 3-8 times prior to their event. The agency supervisor provided an environment of support where students were able to interact and receive guidance.

A variety of projects can sometimes lead to confusion for students (Keshock et al., 2012) especially when it comes to what students believe they will get out of the experience. At the beginning of the semester students frequently compare their project to others based on a number of factors: group size, size of the event, whether it is a new or repeat event and how much money the partner agency has allocated for the event. In spite of the wide variety of projects a consistent theme in the papers was that of being able to learn "hands-on" what students would not be able to learn in the classroom namely, problem-solving and conflict management, time management and marketing techniques. This experiential learning played a key role in the development and learning of the students.

\section{Study Limitations}

There are several aspects of this study which may limit the findings. First, the fact that reflection papers were graded may have influenced student responses. The researchers attempted to minimize this by emphasizing numerous times that the content itself was not being graded, just how well they did or did not attempt to answer the questions. In addition, the primary instructor did not see any of the reflection papers until after the semester ended so as to not be influenced by specific comments any students were making in their reflection papers. Second, in each of the semesters there were many different opportunities to which the students could have been assigned. Different agency types, different agency supervisors and different types and scale of events most assuredly led to different experiences for students. While this is not an unusual occurrence (see Keshock et al., 2012; Ruan et al., 2011), it does create a limitation in that no two projects were exactly the same which limits the generalizability of the data. The next potential limitation is related to data coding. The content analysis conducted was conceptual rather than relational. With few exceptions, noted earlier in the methods section, the researchers relied on 
the specific words used by the students. They did not delve any deeper into what a student may or may not have meant by using certain terms. Additionally, because it was a content analysis only the researchers were unable to identify if there were different levels of competency being identified. This leads to the next limitation. There was no member checking to see if the researchers were interpreting the data the way in which the students meant it to be understood. The researchers worked to minimize this problem by double coding and verifying how the various terms were coded. The final limitation relates to demographics of the participants. The only data collected was gender and age which makes it impossible to know if other demographic factors may have influenced the outcomes.

\section{Implications}

Service learning benefits students (i.e., Keshock et al., 2012; Ruan et al., 2011). Students report being more prepared for working upon graduation and agencies report that our students enter the workplace more qualified because of their experience. As educators, we can attest to the higher test grades, improved class discussions and feedback from students and community partners through service learning projects. However, as recreation programs and classroom numbers grow across the nation and instructors are asked to stretch resources more thinly, the idea of inherent and implied learning may be insufficient to substantiate students and teachers spending the time necessary to coordinate and complete these learning opportunities.

How do we as researchers translate "prepared students" into statistics that clearly detail exactly what our students learn through out of class experiences and how those relate to the competencies required to be a successful recreation professional? Although this study only offers conceptual analysis of data and is therefore somewhat limited, it does illustrate what is found in the literature and provides support for the anecdotal information that we have. This study also provides evidence of the merits of service learning for increasing entry-level competencies in the recreation field. For example, students continually reported that effective problem solving and conflict management skills, marketing techniques, and time-management skills were not only competencies acquired through this project but also concepts that they felt they could not have learned in the classroom.

Research in the field of service learning has continued to increase over the last 20 years as has research related to entry-level competencies for graduates of recreation programs. While these two areas of research grow, there has been little done to link the two subjects together. If it is true that students are more confident once they've experienced competencies, as educators, we have a responsibility to connect classroom work to real-world experience (Hurd et al., 2014). Research of this nature is necessary to justify the continuation of service learning and application in recreation programs.

\section{Acknowledgements}

Support for this research was provided by two internal grants from the University. The initial research design and data collection were supported by a Service Learning Faculty Fellowship. Additional support for data analysis and construction of this paper were provided through the College of Education Mentoring Program. 


\section{Appendix}

Appendix 1. Entry-level Competencies identified by Hurd et al. (2008).

\section{Business Acumen}

1 Understand financial processes (i.e., purchasing, budget).

2 Develop, monitor, and stay within a budget.

3 Possess knowledge of management principles.

4 Demonstrate basic knowledge of laws and legal matters affecting the field.

5 Understand technology and how to use it.

Communications

6 Clearly communicate with staff, customers, and the public.

7 Possess effective written and oral communication skills.

8 Listen to staff and customers.

9 Implement marketing techniques.

10 Communicate the organization's values, vision, and mission.

Community Relations

11 Know the community and its needs.

12 Understand customer service practices.

13 Have the ability to deal with the public.

14 Develop partnerships with other organizations.

15 Work with boards and elected officials.

Interpersonal Skills

16 Be creative and innovative.

17 Be flexible.

18 Have patience.

19 Be enthusiastic and have a positive attitude.

20 Be open-minded.

21 Deal with personality conflicts.

22 Understand the concept of criticism and accept constructive criticism.

23 Take initiative.

Management Techniques

24 Use effective problem-solving and conflict-resolution skills.

25 Make ethical decisions.

26 Understand the hiring process.

27 Supervise, discipline, and evaluate a diverse staff.

28 Motivate employees.

29 Have leadership skills and abilities.

30 Be able to work in a team.

31 Use effective organizational skills.

32 Prioritize and manage multiple tasks.

33 Demonstrate effective time-management skills.

34 Conduct program evaluations.

35 Schedule programs, leagues, and staff.

36 Network within and outside the profession.

37 Participate in policy formation, evaluation, and revision.

Planning and Evaluation

38 Provide input on strategic, master, recreation, marketing, and technology plans.

39 Conduct research and evaluation.

40 Conduct needs assessments. 


\section{References}

Allen, J., O'Toole, W., McDonnell, I., Harris, R., \& Stokes, R. (2005). Festival and special event management ( $3^{\text {rd }}$ ed). Milton, Qld.: Wiley.

Astin, A.W., \& Sax, J. L. (1998). How undergraduates are affected by service participation. Journal of College Development, 39(3), 251-263.

Bandura, A. (1986). Social foundations of thought and action: A social cognitive theory. Englewood Cliffs, NJ: Prentice-Hall.

Barcelona, B, Hurd, A. R., \& Bruggeman, J. A. (2011). A competency-based approach to preparing staff as recreation and youth development leaders. New Directions for Youth Development, 130(Summer 2011), 121-139. doi: 10.1002/yd.401

Barcelona, B., \& Ross, C. M. (2004). An analysis of the perceived competencies of recreational sport administrators. Journal of Park and Recreation Administration, 22(4), 28-46.

Batchhelder, T. H., \& Root, S. (1994). Effects of an undergraduate program to integrate academic learning and service: Cognitive, prosocial cognitive and identity outcomes. Journal of Adolescence, 17(4), 341-355. doi: 10.1006/jado.1994.1031

Bernacki, M. L., \& Jaeger, E. (2008). Exploring the impact of service-learning on moral development and moral orientation. Michigan Journal of Community Service Learning, 14(2), 515 .

Bocarro, J. (2003). Maintaining the balance between service and learning: The use of journals in promoting critical thinking. SCHOLE: A Journal of Leisure Studies and Recreation Education, 18, 7-21.

Bringle, R., \& Hatcher, J. (1997). Reflection. College Teaching, 45, 153-158. doi: $10.1080 / 87567559709596221$

Busch, C., De Maret, P., Flynn, T., Kellum, R., Le, S., Meyers, B., \& Palmquist, M. (2014). Writing@CSU Writing Guide: Content Analysis. Retrieved May 23, 2014, from http://writing.colostate.edu/guides/guide.cfm

Busser, J. A., \& Bannon, J. J. (1987). Work activities performed by management personnel in public leisure service organizations. Journal of Park and Recreation Administration, 5(1), 1-16.

Coetzee, B. A., \& Bloemhoff, H. J., \& Naude, L. (2011). Students' relections on attainment of competencies in a community service-learning module in human movement science. African Journal for Physical, Health Education, Recreation and Dance, 17(3), 547-563. doi: 10.4314/ajpherd.v17i3.71107

Cohen, J., \& Kinsey, D.F. (1994). Doing good and scholarship: A service learning study, Journalism Educator, 48(4), 4-14. doi: 10.1177/107769589304800402 
Cooke, C. A., \& Kemeny, M. E. (2014). Student perspectives on the impact of service learning on the educational experience. SCHOLE: A Journal of Leisure Studies and Recreation Education, 29(1), 102-111.

Cornwell, T. (2010). Sponsorship-linked marketing development. Sport Marketing Quarterly, 4(4), 13-24.

Council on Accreditation of Parks, Recreation, Tourism and Related Professions (2014). Learning Outcomes Standards and Assessments, Adopted Oct 2008, revised April 2014, accessed on May 16, 2014 retrieved from:

http://www.nrpa.org/uploadedFiles/nrpa.org/Professional_Development/Accreditation/COAPRT /2013\%20COAPRT\%20Standards_04-24-14.pdf.

Crossley, J. C., Jamieson, L. M. \& Brayley, R. E. (2007). Introduction to commercial recreation and tourism: An entrepreneurial approach ( $5^{\text {th }}$ ed.). Champaign, IL: Sagamore.

Creswell, J. W. (2009). Research design: Qualitative, quantitative, and mixed methods approach ( $3^{\text {rd }}$ ed.). Thousand Oaks, CA; SAGE Publications.

Cucina, I., \& McCormack, L. (2001). A student-centered community-service project for higher education. Journal of Physical Education, Recreation \& Dance, 72(9), 47-50. doi: 10.1080/07303084.2001.10605867

Engberg, M. E., \& Fox, K. (2011). Exploring the relationship between undergraduate servicelearning experiences and global perspective-taking. Journal of Student Affairs Research and Practice, 48(1), 85-105. doi: 10.2202/1949-6605.6192

Flores, D. (2011). Email communication received April 5, 2011.

Giles, D. E., \& Eyler, J. (1994). The impact of a college community service laboratroy on students' personal, social, and cognitive outcomes. Journal of Adolescence, 17, 327-339. doi: 10.1006/jado.1994.1030

Hammersley, C. H., \& Tynon, J. F. (1998). Job competencies of entry level resort and commercial recreation professionals. Journal of Applied Recreation Research, 23(3), 225-17.

Hendricks, W.W., \& Miranda, B. (2003). A service-learning approach in wilderness education. Journal of Physical Education, Recreation \& Dance, 74(7), 1-4. doi:

10.1080/07303084.2003.10609232

Housman, J., Meaney, K. S., Wilcox, M., \& Carazos, A. (2012). The impact of service-learning on health educations students' cultural competence. American Journal of Health Education, 42(5), 269-278. doi: 10.1080/19325037.2012.10599245

Hurd, A. R. (2004a). Competency development for board members in public park and recreation agencies. Journal of Park and Recreation Administration, 22(4), 43-62. 
Hurd, A. R. (2004b). Keys to individual and agency success. Parks \& Recreation, 39(11), 44-50.

Hurd, A. R. (2005). Competency development for entry level public parks and recreation professionals. Journal of Park and Recreation Administration, 23(3), 45-68.

Hurd, A. R., Barcelona, R. J., \& Meldrum, J. T. (2008). Leisure services management. Champaign, IL: Human Kinetics.

Hurd, A. R., \& Buschbom, T. (2010). Competency development for chief executive officers in YMCAs. Managing Leisure, 15(1), 96-111. Doi: 10.1080/13606710903448186

Hurd, A. R., Elkins, D. J., \& Beggs, B. A. (2014). Using competencies to assess entry-level knowledge of students graduating from parks and recreation academic programs. SCHOLE: A Journal of Leisure Studies and Recreation Education, 29(1), 51-59.

Hurd, A. R., \& McLean, D. D. (2004). An analysis of perceived competencies of CEOs in public park and recreation agencies. Managing Leisure, 9, 96-111. doi:

10.1080/13606710410001709626

Jamieson, L. M. (1987). Competency-based approaches to sport management. Journal of Sport Management, 1(1), 48-57.

Janes, P. C. (2006). Marketing in leisure and tourism: Reaching new heights. State College, Pa.: Venture Pub., Inc.

McCarthy, A. M., \& Tucker, M. L. (2002). Encouraging community service through service learning. Journal of management education, 26, 629-647. doi: 10.1177/1052562902238322

Meaney, K., Griffin, K., \& Bohler, H. (2009). Service-learning: A venue for enhancing preservice educators' knowledge base for teaching. International Journal for the Scholarship of Teaching and Learning, 3(2), 1-17.

Meaney, K. S., Housman, J., Cavazos, A., \& Wilcox, M. L. (2012). Examining service-learning in a graduate physical education teacher education course. Journal of the Scholarship of Teaching and Learning, 12(3), 108-124.

Moorman, M. K., \& Arellano-Unruh, N. (2002). Community service-learning projects for undergraduate recreation majors. Journal of Physical Education, Recreation \& Dance, 73(2), 4252. doi: 10.1080/07303084.2002.10607753

Morgan, W., \& Streb, M. (March 2001). Building citizenship: How student voice in servicelearning develops civic values. Social Science Quarterly, 82(1), 155-169. doi: 10.1111/00384941.00014

Mumford, V., \& Kane, J. (2006). Service-learning in sports. Journal of Physical Education, Recreation \& Dance, 77(3), 38-43, 47. doi: 10.1080/07303084.2006.10597843 
Olsen, H. M., \& Burk, B. (2014). Using reflection to assess students' ability to learn and develop leadership skills. SCHOLE: A Journal of Leisure Studies and Recreation Education, 29(1), 7590.

Ostiguy, L., \& Hopp, R. (1995). Partners in inner-city youth programming. Journal of Physical Education, Recreation \& Dance, 66(4), 32-33. doi: 10.1080/07303084.1995.10608132

Petersen, J. C., Judge, L., \& Pierce, D. A. (2012). Conducting a community-based experientiallearning project to address youth fitness. Journal of Physical Education, Recreation \& Dance, 83(9), 30-36. doi: 10.1080/07303084.2012.10598793

Reed, V., Jernstedt, G. C., Hawley, J. K., Reber, E. S., \& DuBois, C. A. (2005). Effects of a small-scale, very short-term service-learning experience on college students. Journal of Adolescence, 28(3), 359-368. doi: 10.1016/j.adolescence.2004.08.003

Riley, K. (2006). Service-learning evaluation projects: A step-by-step guide. Journal of Physical Education, Recreation \& Dance, 77(6), 39-43, 54. doi: 10.1080/07303084.2006.10597893

Ruan, B., Edginton, C. R., Chin, M. K., \& Ching Mok, M. M. (2011). A pathway to an integrative/holistic education: Camp Adventure Child and Youth Services (CACYS) - a model service learning programme. World Leisure Journal, 53(3), 186-205. doi:

10.1080/04419057.2011.606827

Sax, L., \& Astin, A.W. (1997). The benefits of service: Evidence from undergraduates. The Educational Record, 78(3-4), 25-32.

Schunk, D. H. (2004). Social cognitive theory. Learning theories: An educational perspective (4th ed., pp. 83-135). Upper Saddle River, NJ: Pearson Education.

Smith, D. (2003). Preparing Students to Make a Difference: Community Asset Mapping as a Vehicle for Involving Students in Community Action. SCHOLE: A Journal Of Leisure Studies And Recreation Education, 18(1). Retrieved from http://js.sagamorepub.com/schole/article/view/207. Date accessed August 14, 2012.

Stevens, C. A. (2008). Service learning for health, physical education and recreation. Champaign, IL: Human Kinetics.

Stringer, L. A., \& Kowalski, C. L.(2003). "Peer" into success: Students as peer advisors in leisure and recreation departments. SCHOLE: A Journal of Leisure Studies and Recreation Education, 18, 81-94.

Werner, J. (2011). Email communication received March 30, 2011.

Williams, A., \& Lankford, S. (1999). Service learning: You can get there from here. SCHOLE: A Journal of Leisure Studies and Recreation Education, 14(1). Retrieved from http://js.sagamorepub.com/schole/article/view/277, Date accessed August 14, 2012. 